\title{
Kids on board: Methodological challenges, concerns and clarifications when including young children's voices in tourism research
}

\begin{abstract}
A knowledge gap exists concerning the dearth of children's voices in tourism research. One of the main reasons for this is attributed to the methodological challenges that confront researchers when interacting with child respondents. Based on a recent study conducted with young children between the ages of 5 and 6 , this article discusses five methodological issues to contemplate prior to conducting research with children. This article raises important considerations for children's developmental phase, the use of appropriate props and prompts during data collection, and the positionality and pre-requisites of the researcher when designing methodologies for research with children.
\end{abstract}

Keywords: children, family tourism, qualitative, interview, methodology

\section{Introduction}

Early studies in family tourism have corroborated that children have relatively little persuasion power on family vacation decisions (Beatty \& Talpade, 1994; Howard \& Madrigal, 1990; Shaw, 1997). Thornton, Shaw, and Williams (1997) found that children do not have much say on the amount of money their families spent on holidays. In addition, Wang, Hsieh, Yeh, and Tsai (2004) noted the absence of children's influence in the final stages of family tourism decisions. Recent studies however argue the fact that children cocreate the travel experience with parents (Khoo-Lattimore, Prayag, \& Cheah, 2015), influence their parents' decision-making (Gram, 2007; Nanda, Hu, \& Bai, 2007; Shoham \& Dalakas, 2005) as well as sway demand for tourism products to their favour (Lawlor \& Prothero, 2011; Therkelsen, 2010; Turley, 2001; Webster, 2012). Yet, their perspectives are still very much absent in tourism research (Poria \& Timothy, 2014). One of the reasons for this could be that research on family tourism is still in its infancy. Another reason could be due in part to the held beliefs that children are passive members of the family who have comparatively little or 
no impact on holiday decision-making processes (Foxman, Tansuhaj, \& Ekstrom, 1989; Schänzel, Smith, \& Weaver, 2005). A further deterrent factor for explaining the lack of children's voice in tourism research could be the ethical approval committees for research on children, who are typically more demanding given society's highlight on child safety and protection (Carr, 2011). Another reason, as Poria and Timothy (2014) argue, could be attributed to the presumption that scholars who want to conduct studies with children and/or on children need to have acquired specialised research techniques that hint at knowledge and skills in early childhood education. Nanda et al (2007) in their review of literature on family roles in holiday decision-making have attempted to recommend 'unique research methods' (p.119) for including children in families but provided little guidance for doing so.

As such, an increasing number of scholars have called for the inclusion of children's voices to better understand their influence on family travel and tourism experience (Carr, 2011; Cullingford, 1995; Henderson, Whitaker, Bialeschki, Scanlin, \& Thurber, 2007; KhooLattimore et al., 2015; Poria \& Timothy, 2014; Schänzel et al., 2005; Shaw, Havitz, \& Delemere, 2008). This article extends these calls by laying the foundations for a qualitative methodological framework for research with children. It will draw upon experiences from two recent studies with young children as well as a broad base of literature from consumer research, tourism, psychology and education. The work here aims to develop understanding of the complexities and obstacles of conducting qualitative research on children. More specifically, the objective of this article is to advance the scholarship of researchers wishing to gain information about the holiday experiences of young children. Epistemologically, the researcher is an interpretivist, and ontologically a realist (Frazer \& Lacey, 1993). This means that there is belief in, "a real world that exists independently of our perceptions, theories and 
construction" yet also acceptance that, "our understanding of this world is inevitably a construction from our own perspectives and standpoint" (Maxwell, 2012, p.5).

\section{Children in tourism research}

Much research in marketing has established that children typically influence family purchases at various stages of the decision-making process (see for examples, Beatty \& Talpade, 1994; Beneke, Silverstone, Woods, \& Schneider, 2011; Jeevananda \& Kumar, 2012; Kerrane, Hogg, \& Bettany, 2012; Tripathi \& Sengupta, 2011; Ward \& Wackman, 1972; Wilson \& Wood, 2004). Within tourism, we have also recognized the influence of children in family holiday decision-making (Carr, 2006; Howard \& Madrigal, 1990; Nanda et al., 2007; Nickerson \& Jurowski, 2001; Segumpan, Zahari, \& Jamaluddin, 2008; Tagg \& Seaton, 1995; Therkelsen, 2010; Thornton et al., 1997; Wang et al., 2004). Some work has revealed that older children have more influence than younger children in family tourism decisions (Darley \& Lim, 1986; Tagg \& Seaton, 1995; Therkelsen, 2010), while others argue that influence may not necessarily increase with age (Thornton et al., 1997; Wang et al., 2004). Rather, other factors of influence can be attributed to household income, for example, children in double income families have significantly more influence than children in single income families (Wang et al., 2004). Tourism scholars have also concluded that children have the greatest influence on their family holiday destinations (Howard \& Madrigal, 1990) as well as the types of food consumed during these holidays (Segumpan et al., 2008). Children affect the types of activities families do while on vacations (Howard \& Madrigal, 1990; Thornton et al., 1997). We also know that while in general, children do not exert control in determining family spending during vacations (Segumpan et al., 2008), adolescent children exercise considerable authority in family decisions for tourism products purchased through the internet (Liang, 2013). It has also been established that the presence of younger children impacts family 
holiday schedules (Davidson, 1996) and choice of accommodation (Khoo-Lattimore et al., 2015). More importantly, we have now acknowledged that children and their parents may have differing views about the multiple facets of the family vacation (Carr, 2006; Johns \& Gyimóthy, 2003; Nickerson \& Jurowski, 2001; Schänzel, 2012). Despite these studies, our understanding of children in tourism is still very much limited for two main reasons.

Firstly, existing studies revealing children's roles in family vacations have been conducted mostly from adults' perspective, through the voices of either their parents (see for examples, Lehto, Choi, Lin, \& MacDermid, 2009; Segumpan et al., 2008; Thornton et al., 1997; Turley, 2001) or other adult stakeholders (Gaines, Hubbard, Witte, \& O'Neill, 2004). For instance, when investigating children's programmes in family-catering hotels and resorts (Gaines et al., 2004), data was obtained from children's program staff working at various hotels and resorts - not children themselves. Thornton et al. (1997) concluded that children influence their family's travel activities and behaviour based on the diaries collected from adults with and without children. These studies are principally predicated upon the 'childrenas-passive-objects' framework and assume that the child is not yet physically, socially or psychologically ready as a legitimate research participant. This approach of data collection from parents and other adults, although methodologically rigorous, has been criticised for its many limitations. For one, the adults' assumptions, attitudes and expectations about family holidays will taint information about the children's needs, wants and experiences (Henderson et al., 2007; Punch, 2002). Furthermore, non-tourism studies conducted with children have revealed results that adults did not at first expect (McNeal, 1992; Young \& Barrett, 2001). These findings point to a potential gap between what parents think they know about their children and what children actually like or dislike about various aspects of their family holidays (Henderson et al., 2007). 
The notion of children as passive social agents in family tourism (Ryan, 1992) however, is 'an increasingly dated view that has been replaced by the recognition that children are actually active agents in their own lives, in those of their immediate family members, and in the wider society in which they are situated' (Carr, 2011, p. 11). To address the limitations of the studies that adopt this view, scholars have applied the more encompassing wholefamily approach (Schänzel, 2010; Schänzel \& Smith, 2014), where children's perspectives are taken into consideration along with those of their family members'. These studies embrace principles underlying contemporary families and recognise the increasing level of personal child agency in terms of family consumption. Tagg and Seaton (1995), after their extensive survey on both parents and children, confirmed that children do influence family decisionmaking when holidays are concerned. Therkelsen (2010) validates this finding with her own qualitative interviews with parents and children of 16 German and 10 Danish families. Nickerson and Jurowski (2001)'s study extends this understanding with their quantitative surveys administered on both adults and children. Their study found that children differ in their opinions about holidays from their parents. Similarly, Gram (2005)'s analysis of 49 children from 16 German and 10 Danish families reported differences in the ways holidays are perceived by parents and children. Johns and Gyimóthy (2003) provided some more insights from their 35 interviews with families that included children - that while children and parents share many similar views on their visit to Legoland, the children's notion of 'family' differs from that of their parents. Carr (2006) whose study involved 54 parents and 66 adolescent children adds to our understanding of children on family holidays. He revealed that even though parents and adolescent children go on holidays to relax and escape from daily responsibilities, parents are more oriented towards educational and cultural holidays while adolescents are more motivated by fun and physical activities. The definition of fun for 
parents and children can conflict, as evidenced in Schänzel (2012)'s study involving 20 parents and 20 children between the ages of 6 and 16. Hilbrecht, Shaw, Delamere, and Havitz (2008) also uncovered this notion of fun when they interviewed 24 children alongside their families and confirmed previous findings that children experience family leisure differently from their parents. More recently, Liang (2013) in surveying both children and their parents, revealed that children who have proficiency with the Internet have greater influences on their parents for online purchases of tourism products. These studies must be commended for their exploration of tourism issues from children's own perspective for they have in fact, developed some nuanced understandings of children as travellers. However it can also be argued that their dyadic (parent-child) and triadic (father, mother, child) approaches could mean that the child is still not recognised as a free, active social agency. The children's views are not necessarily free from their parent's, particularly if they were interviewed or surveyed together with their parents (as in the case of Gram (2005) and Therkelsen (2010)), hence inviting the potential threat of dominance bias (Goodwin, Operario, \& Fiske, 1998) in the data. Handel, Cahill, and Elkin (2006) have already cautioned the fact that children can behave differently in the presence of their parents than when their parents are absent. Therefore, despite the studies that have included children as participants within tourism, Poria and Timothy (2014) declared that there is almost no empirical studies on children's voices.

One of the earliest studies in tourism inviting exclusively children and young people to be active research participants is Cullingford (1995). His investigation of children's attitudes to holidays overseas employed a large pool of 160 children between the ages of seven and 11 who were interviewed via a semi-structured protocol. Small (2008) conducted focus groups with 86 females on their meanings of childhood holidays, about a quarter of them were girls aged 12. Blichfeldt, Pedersen, Johansen, and Hansen (2011) explored children's influence in 
family holiday decision-making with 89 children between the ages of eight and 12 . These children were asked to draw pictures and interviewed in focus groups of two or more. The study adds to our understanding of how children perceive their own roles in the family holiday decision-making process - the children in the study did not see themselves as 'passively submitting to whatever choices their parents make; nor do they resemble the stereotypic image of self-centred and pestering individuals in search of their own identity (or identities)' (Blichfeldt et al., 2011, p. 135). Compared to the negative strategies of pestering that scholars (or their parents) say children use, the approach that focusses solely on children's viewpoints have revealed the more positive ways in which children influence family holiday decisions. These alternative insights are important for the tourism industry especially when considering strategies for catering and communicating to children and families with children. Yet, there still exists a dearth of tourism-related knowledge that is examined from the perspectives of children.

Another observation within this scarcity is the absence of young children's voices in tourism research. While a handful studies have included the voices of children in their research, most of the participants are older children who are already at least in primary schools, with a majority of these participants being teenagers. Nickerson and Jurowski (2001) selected children between the ages of 10 and 17 specifically for their reading ability while Blichfeldt et al. (2011)'s participants were 8 and 12 years old. The children in Tagg and Seaton (1995), Carr (2006), Small (2008) and Liang (2014) were of similar age-groups, between 12 and 18. In all the tourism studies that include children, the youngest recorded age for participation is five (Hilbrecht et al., 2008), six (Schänzel, 2012; Schänzel \& Smith, 2014) and seven (Cullingford, 1995; Gram, 2005). Hilbrecht et al. (2008) who attempted to include a few children as young as five in their pool of 24 reported that these younger participants 
needed their parents during the interview, which resulted in the latter imposing on the children's responses. They also informed that while their interviews with older children lasted 45 minutes, the ones with younger children were only 15 minutes long. Schänzel and Smith (2014) divulged that children's contributions were not as profound as their parent's. While tourism scholars are increasingly including the perspectives of children, the voices of young preschool children are still very much missing.

\section{Young, preschool children}

From the literature, it seems as if the younger the children, the more marginalised they are in their representation of bodies within tourism. This could be largely attributed to the belief that either young children are not yet competent social actors in their own right, or/and do not possess the verbal and conceptual competence to communicate their experiences. Therkelsen (2010) in her study involving all members of the family, reported that, 'generally, all of the family's members participated, though in families with young children, interviews were conducted without any significant input from children' (p. 771). Johns and Gyimóthy (2003) reported that their interviews with children returned few concepts. Carr (2011) also gave another example of an Australian study that failed to obtain the desired information from children aged 4 and 5 .

This is surprising because much work in psychology has shown that by age 3 , majority of children are able to provide extended and relatively coherent descriptions of their past experiences (Fivush \& Haden, 2003; Fivush \& Hamond, 1990; Fivush \& Shukat, 1995; Nelson \& Fivush, 2004). This ability for autobiographical recall develops in complexity and organisation and becomes not only stable but accurate between the ages of 3 and 5 (Fivush \& Hamond, 1990). Furthermore, Gross and Hayne (1998) have demonstrated that 3 to 6 year olds can express their thoughts on a range of complex issues such as death, divorce and 
family conflicts. Other academic evidence also point to the ability of 5 and 6 year olds to work on a task for more than an hour (Ruff \& Lawson, 1990), implying that they would be fitting candidates for interviews or surveys. Matthews (1998) has also established that interviews can be conducted with children as young as five years old. It is this disparity between preschool children's potential as participants and the absence of their voice in tourism research that motivates this study.

\section{The empirical study}

The study began in 2013 with an aim to understand children's preferences for accommodation attributes during their family holidays. The objective was to contrast the findings with those from a recent study on Asian parents' choice criteria of resort hotels when holidaying with young children (Khoo-Lattimore et al., 2015). Therefore, similar to Khoo-Lattimore et al (2015), this study was also conducted in Malaysia. Based on convenience and snowball sampling methods, principals of preschools were contacted for permission to carry out focusgroup interviews with children. The decision to recruit respondents through schools is thought to be pragmatic for logistical reasons such as the ease accorded to organising focus group space and times and obtaining consent from parents. Seeking consent from parents is not uncommon in research with children (Greenfield, 2004), typically for those under the age of 18. However, in hindsight, although all the children seemed enthusiastic during data collection, a child's consent form should have been utilised to allow any child the opportunity to refuse participation. It has been found that children as young as four year old are 'competent and capable regarding giving consent' (Hedges, 2002, p. 39).

The focus-group method was deliberate, as guided by the literature that positions small focus groups as the most common and natural form of communication in which children interact with each other (Eder \& Fingerson, 2002; Gibson, 2012). In addition, focus group is 
commonly used in marketing research involving children, even though these groups mostly featured parents and sometimes parents with children but less frequently with only children (Nickerson \& Jurowski, 2001). The option to interview children individually was rejected in view of Blichfeldt et al. (2011)'s experience and advice. Three focus groups were arranged, each with six children between the ages of 5 and 6 . Three research assistants (RA1, RA2 and RA3) were employed to conduct the focus group interviews with children. All three were present at each focus group. Given that children in this age group are developing symbolic thought (Piaget \& Inhelder, 2013), the participants were encouraged to draw pictures of a family holiday they had been to.

At the completion of this task, the children were invited to circle time where the three research assistants conducted the interviews, using the children's pictures as prompts. The interviews were video as well as audio-recorded, and then transcribed verbatim. Although transcripts from the interviews revealed some understanding of children's like and dislikes during family holidays, data analysis was highly challenging because the interviews were mainly filled with incomplete expressions of thoughts, trivial chats, and insubstantial material. As a consequence, a second round of data was collected. The second data collection follows the same procedure as the first with two exceptions. First, instead of employing research assistants, the researcher alone conducted all three focus groups. Second, the focus groups were conducted between the hours of 10.30 am and $12 \mathrm{pm}$. Analysis from this second round of interviews returned substantially higher quality data. The following section highlights five methodological directions, drawn from the reflection of the two phases of the same study as well as the literature on interviewing young children. 


\section{Methodological challenges, concerns and clarifications: The 5Ps}

\section{Participant's phase of development}

The children in this study were 5 and 6 years old, which in Malaysia, are preschool ages. It is acknowledged that in other countries, formal primary education can begin as early as five years old. In any case, extracting data from children of this age group can be daunting (Nickerson \& Jurowski, 2001), given the presumption that preschool children have little eye for detail and do not possess characteristics of maturity (Valkenburg \& Cantor, 2001) - this view could well explain the absence of young children's voices in tourism research thus far. However, James and Prout (1997) have also said, 'The immaturity of children is a biological fact of life, but the ways in which this immaturity is understood and made meaningful is a fact of culture' (p.7). Researchers need to consider their young participants' developmental phase related to their age. In quantitative surveys, researchers need to consider for example the length of the questionnaire, as well as the terms and scales used in the instrument. The language used should be clear and simple to children (Conroy \& Harcourt, 2009) so perhaps instead of the traditional Likert scale, preferences or satisfaction can be polled using smiley and sad faces. In interviews, researchers must contemplate children's mastery of vocabulary for the expression of thoughts that will be comprehensible to researchers. At 4 years old, pronunciation for children can still be imprecise hence in this study, the minimum age threshold was set at 5 years old. At 5 , children have a wide range of word vocabulary enough to tell long stories, are interested in questions, can argue and give their own opinions about things (Berk, 2001; Harding, 2013). In addition, class teachers were enlisted to help pre-select children whom they think are more developmentally suitable for the task, i.e. those who are more able to focus their attention for longer, have a larger command of vocabulary and more expressive than others. 
Besides their cognitive and language competencies, it is also important for researchers to take into account children's psychological and physiological needs. In the first study for example, the failure to plan according to these needs resulted in some disorder approximately 13 minutes into the interview, with RA1 saying, 'He wants to go for his snack. Okay, 5 more minutes okay? 5 more minutes, if you answer quickly then we can go'. It is important for researchers to plan for the investigation period to occur outside children's feed and sleep schedules and to consider optimal attention periods that correspond with the development phase of their young participants (Berk, 2001). In the subsequent stage, focus groups were planned for 10.30 am, which followed immediately after the children's snack and toilet time. No logistical disruption was observed in all three focus groups during the second study.

\section{Props}

Another important consideration related to children's phase of development is the utilisation of props and prompts during data collection. In this study, the children's own drawings were used as a prop for stimulating discussions about their holiday experience. The use of drawings has been highly recommended as a child-led data collection method for allowing recall when interviewing children about past events (Barlow, Jolley, \& Hallam, 2011; Gross \& Hayne, 1999; Mitchell, 2006; Young \& Barrett, 2001). Particularly for this age group of 5 and 6 year olds, research has found that drawing facilitates verbal reports of past events as far back as 6 months (Gross \& Hayne, 1999). The drawing activity also allows children time to consider about what they wish to portray and talk about. One tourism study with children that employed children's drawings as props is that of Gram (2005) and possibly Therkelsen (2010).

Other visual methods of data collection that may be suitable for young children include the utilisation of photographs taken by children themselves (Carr, 2011; Punch, 2002; 
Schänzel \& Smith, 2011; Young \& Barrett, 2001). In the second study, the children were given an opportunity to complement their drawings with building blocks and play dough. However, all children in three focus groups concentrated only on their drawings and did not utilise the blocks or dough. It is therefore recommended that these props be used for triangulation purposes where the same children could be interviewed again on the topic using a different prop. In addition to blocks and play dough, ventriloquism was also used in the second study - a character named 'MooMan' introduced himself and the project to the children. Puppets were sometimes used to substitute the researcher as the interviewer to better engage the participants. Ventriloquism is also an effective way to address the criticisms and problems associated with using adults as researchers to interview children (McNeal, 1992). The children in this study were observed to be less intimidated by 'MooMan' and more enthusiastic to expressing their views. This finding is consistent with Mandell (1988) who called for researchers to assume the least-adult role that minimises physical differences and to interact with children within their perspective.

\section{Prompts}

Given that the language of young children is still limited, they may express experience differently from adults hence many studies that work with children have focussed on the importance of listening to children so that their views and not the researcher's are accurately captured (Carr, 2011; Cullingford, 1995; Poria \& Timothy, 2014; Punch, 2002). Less emphasis however has been given to the questioning techniques and how best to encourage detailed responses from participants as young as 5 years old. The research assistants in the first study were trained in interview techniques that include prompting for answers but their experiences were limited to interviewing adults. For example, the question 'why' was frequently used in the first study: 
- 'Why don't you like papaya?'

- 'Why do you like to stay in the hotel?'

- 'You like cupcakes and cookies? Why?'

- 'Why do you like swimming pool?'

- 'Why are you scared?'

- 'Why would your family laugh at you?'

On hindsight, these 'why' questions are not appropriate as a prompt for children of this age group because they are not yet able to make inferences or justify their thoughts and behaviour. Even in cases of older children who are more advanced in their cognitive development, there is advice for researchers to avoid using 'why' questions so children do not feel that they have to constantly defend their views of their experiences (Gibson, 2012). Therefore, in the second study, a variety of prompts more suitable to the developmental phase of this age group were deliberately employed. Prompts were more carefully phrased for the pre-schoolers. For example, instead of, 'Why do you like swimming pool?' which generated, 'I went to another place, and I have swimming pool again', they were asked, 'Tell me more about the swimming pool!' Responses included, 'The slide of the pool', 'My daddy plays with me and my baby sister in the pool', and 'My mummy is cool in the pool [chuckles], nobody in my family is angry when we are in the pool'.

\section{Positionality of the researcher}

For many Asian adults, children should be seen and not heard. Asian child-rearing patterns are characterized by authority, obedience and respect for elders (Chao, 1996; Gorman, 1998). As an Asian herself, the researcher understands that these characteristics are inherent during adult-child relationships and communication in everyday Asian society. Therefore, it would not be uncommon to expect the three Asian interviewers in the first phase of the study to have 
exerted subtle strictness and governance over the children (Russell, Crockett, \& Chao, 2010), be this consciously or unconsciously. The researcher is married to a white male, has children in Anglo-Saxon schools and subscribes to the more liberal western concepts of adult-child relationship. The researcher views children as having rights rather than just needs. These inherent assumptions of children in society underlie the organisation and management of the interview sessions, and can influence the quality of data. When comparing transcripts from the two studies, it is noted that in the first phase, the young respondents were 'instructed' by RA1 for answers in a regimented classroom manner, 'Come, we voice out one by one. So QL stayed in a hotel, Z stayed in a hotel, B stayed in a hotel. Why did you like the hotel?' A further example of this is in another focus group, when RA2 commanded, 'Last question. Okay, let's start with KY first and then we will go this side', signalling a clock-wise direction for the next line of responses from the children. How children are positioned in the researchers' minds can inhibit or encourage children's expressions during the interview. Therefore, researchers should first 'identify their positionality and to be aware of how this can influence the nature of the material they collect and how it is analysed' (Carr, 2011, p. 175). When children are viewed as competent informants in their own rights, their views will be obtained in a way that recognizes child agency and consequently, taken seriously.

This position of the researcher should also be the focus of reflexivity during analysis of data obtained from children participants. Whilst children are recognised as active agents with rights, it is equally important to acknowledge that the younger the children, the more potentially susceptible they will be to imbalanced power relationships between them and adult researchers. With younger children, Wyness (2012) highlights the need for adult researchers to consciously enter the worlds and cultures of children so their views are accurately captured. Carr (2011) has called for tourism researchers to 'identify their own positionality and to be aware of how this can influenced the nature of the material they collect and how it is 
analysed' (p. 175). In the first phase of this study, RA1 may have applied her own nostalgia of childhood when she casually commented to another interviewer, 'See, the kids these days...the pictures are different' implying that the children interviewed are advantaged in the way they experience holidays. Another example of researcher interference with data can be seen when the children were talking about the food hotels offer. RA3 imposed her own ideals of food during the interview and exclaimed, 'You don't like papaya? Papaya is good! Why don't you like papaya?' This could have intimidated the children in the group to further express their experiences but with reflexivity on positionality, the researcher can minimise the risk of problematic data interpretations.

\section{Prerequisites for research with children}

The research assistants in the first study were briefed on the task at hand but never guided on the principles underlying children-as-participants or developmental processes of preschoolers. Although one of the three research assistants had a preschool-aged child, it must be professed that all three interviewers were chosen firstly because of their sound knowledge and understanding of qualitative research techniques and secondly, for their pleasant personalities. In any case, Fine and Sandstrom (1988) has cautioned against the 'assumption that might seem valid because we believe we know and understand children, both because we were children once and because we see them so often' (p. 35). Although all three got along well with children, they were not effective in prompting responses from their young respondents. For example, the basic importance of setting ground rules for children groups (Gordon \& Browne, 2013) was taken for granted and not communicated to the research assistants. As a result, many individual children were often interrupted by others in the group and any valuable data about to be expressed was lost. This happened frequently during the first study and there was no instance in the transcript when an interrupting child was asked to allow the person talking to finish what he or she was saying, for example: 
Child 1 : I went to Universal [Studios]. And my house is almost....

Child 2 : I went swimming in the sea.

Another example of this interruption is illustrated as follows:

RA2 : To play? How about Child 1? What did you like about the hotel that you stayed at? Did you like anything about the hotel?

Child 1 : Swimming.

RA2 : You like to swim?

Child 2 : I also like to swim!

Child 3 : I also like to swim!

In the second study, the researcher alone conducted all three focus groups on the premise of her knowledge and experience in early childhood education. The researcher herself has a Master's degree in Educational Psychology, previously owned early childhood education centres in Malaysia and thus, dealt with many pre-schoolers. She also has at the time of the interview, a pre-schooler son but more importantly for this study, she has also acquired a good understanding of theories on children's social and cognitive development from her formal training and work experience. This was pertinent in the many aspects that the interviews were managed and conducted. To begin with, it was made clear to the children that each person will have a chance to talk about their drawing, and when someone is doing their 'show-and-tell', the group will respect that time and not interrupt. In setting these ground rules, the researcher used the term, 'we' as in 'We will listen when others are talking'. The children were taught to recognise a group sign for silence by placing a palm on the head. During the interview, when a child was about to interrupt, the researcher would point to the child with one hand while placing her other hand on her head to signify silence. The establishment and implementation of this rule significantly reduced interrupted responses and lost data. Other rudimentary practices in early childhood education that was contravened during the first study but utilized in the second are the reward and reinforcement of desired 
behaviour (Deiner, 2013; Swiezy, Matson, \& Box, 1993); eye contact (Hiralall \& Martens, 1998), encouragement cues, and the use of play and games during instructions (Warner \& Lynch, 2004). Therefore, novice researchers wanting to interview young children should begin by equipping themselves with knowledge and understanding of preschool group management so as to be able to draw on a number of strategies which will encourage children to participate in the interaction.

\section{Implications and conclusion}

The quality of data generated from the second study is significantly better than from the first. Based on the researcher's experience in the two phases of data collection with 5 and 6 year olds, this article has underlined some strategies for future researchers. The primary determinants which changed the dynamics and directions of the focus group interviews in the context of young respondents, centred upon five methodological considerations - phase of development, props, prompts, positionality and pre-requisites. These five Ps require researchers to understand the development of various competences in children as well as their own skills set for interviewing children. The five Ps ask that researchers appraise their own views regarding children's role and competence and to use appropriate props and prompts that recognise children's rights. The two empirical studies have shown that with the five Ps, research with young children is not only possible but can also produce promising data. This possibility of generating insightful data from young children contradicts earlier reports of children as superficial providers of information.

The considerations presented in this article confirm the notion of children's rights and reiterates the increasing influence of children in contemporary family holidays. Although many researchers recognise children as active agents of change, many have not ventured very far into researching young children. This could be caused by the presumption of daunting 
application processes for ethical approvals to work with minors hence most researchers opt to interview older children or children with their parents. In doing so, researchers have over time adopted approaches that more inclusive of children's voices. However, some more innovative approaches are needed and this article highlights those. Obtaining a child's own consent in addition to that of the parent's is an important step towards recognising the child's own rights. The use of drawings, play dough, Lego blocks and ventriloquism can help tap into children's channels of communication while diction and early childhood classroom management techniques can promote children's ability and willingness to express their views. These approaches are necessary when researching children and families with children so as to gain access to children's minds and voices. This is important given that children are often consumers and/or co-producers of the tourism experience.

As in any qualitative study, there is always the threat of researcher bias in the data collection and analysis stages. In this study, it could have been possible that the researcher's adult values (rather than children's values) have framed some of the questions that were asked in the interviews. In addition, the researcher's decision to conduct the interviews was based on the analysis and reflection of the first study. Although reflexivity is deemed a valid strategy for minimising researcher bias and increasing validity, the researcher's keen interest in the subject matter and her determination to improve young children's participation in the focus groups could have introduced other forms of researcher bias in the collected data. Future research could identify all possible forms of investigator bias in research with young children. It would also be worthwhile for future scholars to examine these methodological considerations against varied contexts such as culture, older or younger age groups and gender. 


\section{References}

Barlow, C.M., Jolley, R.P., \& Hallam, J.L. (2011). Drawings as memory aids: Optimising the drawing method to facilitate young children's recall. Applied Cognitive Psychology, 25(3), 480-487. doi: 10.1002/acp. 1716

Beatty, S.E., \& Talpade, S. (1994). Adolescent influence in family decision making: A replication with extension. Journal of Consumer Research, 21(2), 332-341. doi: $10.1086 / 209401$

Beneke, J., Silverstone, G., Woods, A., \& Schneider, G. (2011). The influence of the youth on their parents purchasing decisions of high-technology products. African Journal of Business Management, 5(10), 3807-3812. doi: 10.5897/AJBM10.359

Berk, L.E. (2001). Development through the lifespan (2nd ed.). Boston, MA: Allyn and Bacon.

Blichfeldt, B.S., Pedersen, B.M., Johansen, A., \& Hansen, L. (2011). Tweens on holidays. Insitu decision-making from children's perspective. Scandinavian Journal of Hospitality and Tourism, 11(2), 135-149. doi: 10.1080/15022250.2011.588444

Carr, N. (2006). A comparison of adolescents' and parents' holiday motivations and desires. Tourism and Hospitality Research, 6(2), 129-142. doi: 10.1057/palgrave.thr.6040051

Carr, N. (2011). Children's and families' holiday experience. Oxon, UK: Routledge.

Chao, R.K. (1996). Chinese and European American mothers' beliefs about the role of parenting in children's school success. Journal of Cross-Cultural Psychology, 27(4), 403-423. doi: 10.1177/0022022196274002

Conroy, H., \& Harcourt, D. (2009). Informed agreement to participate: Beginning the partnership with children in research. Early Child Development and Care, 179(2), 157-165. doi: 10.1080/03004430802666973

Cullingford, C. (1995). Children's attitudes to holidays overseas. Tourism Management, 16(2), 121-127. doi: 10.1016/0261-5177(94)00022-3

Darley, W.K., \& Lim, J.-S. (1986). Family decision making in leisure-time activities: An exploratory investigation of the impact of locus of control, child age influence factor and parental type on perceived child influence. In R. J. Lutz (Ed.), Advances in Consumer Research (Vol. 13, pp. 370-374). Provo, UT: Association for Consumer Research.

Davidson, P. (1996). The holiday and work experiences of women with young children. Leisure Studies, 15(2), 89-103. doi: 10.1080/026143696375648

Deiner, P. (2013). Inclusive early childhood education: Development, resources, and practice (6th ed.). Belmont, CA: Cengage Learning.

Eder, D., \& Fingerson, L. (2002). Interviewing children and adolescents. In J. F. Gubrium \& J. A. Holstein (Eds.), Handbook of interview research: Context and method (pp. 181203). Thousand Oaks, CA: SAGE.

Fine, G.A., \& Sandstrom, K.L. (1988). Knowing children: Participant observation with minors. Newbury Park, CA: SAGE

Fivush, R., \& Haden, C.A. (2003). Autobiographical memory and the construction of a narrative self: Developmental and cultural perspectives. Mahwah, NJ: Psychology Press.

Fivush, R., \& Hamond, N.R. (1990). Autobiographical memory across the preschool years: Toward reconceptualizing childhood amnesia. In R. Fivush \& J. Hudson (Eds.), 
Knowing and remembering in young children (pp. 223-248). Cambridge, UK: Cambridge University Press.

Fivush, R., \& Shukat, J.R. (1995). Content, consistency, and coherence of early autobiographical recall. In M. S. Zaragoza, J. R. Graham, G. C. N. Hall, R. Hirschman \& Y. S. Ben-Porath (Eds.), Memory and testimony in the child witness (pp. 5-23). Thousand Oaks, CA: SAGE.

Foxman, E.R., Tansuhaj, P.S., \& Ekstrom, K.M. (1989). Family members' perceptions of adolescents' influence in family decision making. Journal of Consumer Research, 15(4), 482-491. doi: 10.1086/209187

Frazer, E., \& Lacey, N. (1993). The politics of community: a feminist critique of the liberal communitarian debate. New York: Harvester Wheatsheaf.

Gaines, B.L., Hubbard, S.S., Witte, J.E., \& O'Neill, M.A. (2004). An analysis of children's programs in the hotel and resort industry market segment. International Journal of Hospitality \& Tourism Administration, 5(4), 85-99. doi: 10.1300/J149v05n04_05

Gibson, J.E. (2012). Interviews and focus groups with children: Methods that match children's developing competencies. Journal of Family Theory \& Review, 4(2), 148-159. doi: 10.1111/j.1756-2589.2012.00119.x

Goodwin, S.A., Operario, D., \& Fiske, S.T. (1998). Situational power and interpersonal dominance facilitate bias and inequality. Journal of Social Issues, 54(4), 677-698. doi: 10.1111/j.1540-4560.1998.tb01243.x

Gordon, A.M., \& Browne, K.W. (2013). Beginnings \& beyond: Foundations in early childhood education (9th Ed.). Belmont, CA: Cengage Learning.

Gorman, J.C. (1998). Parenting attitudes and practices of immigrant Chinese mothers of adolescents. Family Relations, 47(1), 73-80. doi: 10.2307/584853

Gram, M. (2005). Family holidays. A qualitative analysis of family holiday experiences. Scandinavian Journal of Hospitality and Tourism, 5(1), 2-22. doi: 10.1080/15022250510014255

Gram, M. (2007). Children as co-decision makers in the family? The case of family holidays. Young Consumers: Insight and Ideas for Responsible Marketers, 8(1), 19-28. doi: 10.1108/17473610710733749

Greenfield, C. (2004). 'Can Run, Play on Bikes, Jump the Zoom Slide, and Play on the Swings': Exploring the Value of Outdoor Play. Australian Journal of Early Childhood, 29(2), 1.

Gross, J., \& Hayne, H. (1998). Drawing facilitates children's verbal reports of emotionally laden events. Journal of Experimental Psychology: Applied, 4(2), 163- 179. doi: 10.1037/1076-898X.4.2.163

Gross, J., \& Hayne, H. (1999). Drawing facilitates children's verbal reports after long delays. Journal of Experimental Psychology: Applied, 5(3), 265-283. doi: 10.1037/1076898X.5.3.265

Handel, G., Cahill, S., \& Elkin, F. (2006). Children and society: The sociology of children and childhood socialization. Los Angeles, CA: Roxbury.

Harding, J. (2013). Child development: An illustrated handbook. Abingdon, UK: Hodder Education.

Hedges, H. (2002). Beliefs and principles in practice: Ethical research with child participants. New Zealand Research in Early Childhood Education, 5(3), 31-49.

Henderson, K.A., Whitaker, L.S., Bialeschki, M.D., Scanlin, M.M., \& Thurber, C. (2007). Summer camp experiences parental perceptions of youth development outcomes. Journal of Family Issues, 28(8), 987-1007. doi: 10.1177/0192513X07301428 
Hilbrecht, M., Shaw, S.M., Delamere, F.M., \& Havitz, M.E. (2008). Experiences, perspectives, and meanings of family vacations for children. Leisure/Loisir, 32(2), 541-571. doi: 10.1080/14927713.2008.9651421

Hiralall, A.S., \& Martens, B.K. (1998). Teaching classroom management skills to preschool staff: The effects of scripted instructional sequences on teacher and student behavior. School Psychology Quarterly, 13(2), 94-115. doi: 10.1037/h0088976

Howard, D.R., \& Madrigal, R. (1990). Who makes the decision: The parent or the child? The perceived influence of parents and children on the purchase of recreation services. Journal of Leisure Research, 22(3), 244-258.

James, A., \& Prout, A. (Eds.). (1997). Constructing and reconstructing childhood: Contemporary issues in the sociological study of childhood (2nd ed.). London, UK: Falmer Press.

Jeevananda, S., \& Kumar, S. (2012). Degree of children influence on parents buying decision process. European Journal of Business and Management, 4(14), 49-57.

Johns, N., \& Gyimóthy, S. (2003). Postmodern family tourism at Legoland. Scandinavian Journal of Hospitality and Tourism, 3(1), 3-23. doi: 10.1080/15022250310001549

Kerrane, B., Hogg, M.K., \& Bettany, S.M. (2012). Children's influence strategies in practice: Exploring the co-constructed nature of the child influence process in family consumption. Journal of Marketing Management, 28(7-8), 809-835. doi: 10.1080/0267257X.2012.698633

Khoo-Lattimore, C., Prayag, G., \& Cheah, B.L. (2015). Kids on board: Exploring the choice process and vacation needs of asian parents with young children in resort hotels. Journal of Hospitality Marketing \& Management. doi: http://dx.doi.org/10.1080/19368623.2014.914862

Lawlor, M.-A., \& Prothero, A. (2011). Pester power - A battle of wills between children and their parents. Journal of Marketing Management, 27(5-6), 561-581. doi: 10.1080/0267257X.2010.495281

Lehto, X.Y., Choi, S., Lin, Y.-C., \& MacDermid, S.M. (2009). Vacation and family functioning. Annals of Tourism Research, 36(3), 459-479. doi: 10.1016/j.annals.2009.04.003

Liang, Y.-W. (2013). Children's influence on purchasing tourism products via the internet: Parental power versus children's power-the social power perspective. Journal of Travel \& Tourism Marketing, 30(7), 639-661. doi: 10.1080/10548408.2013.827543

Mandell, N. (1988). The least-adult role in studying children. Journal of Contemporary Ethnography, 16(4), 433-467. doi: 10.1177/0891241688164002

Matthews, H. (1998). The geography of children: Some ethical and methodological considerations for project and dissertation work. Journal of Geography in Higher Education, 22(3), 311-324. doi: 10.1080/03098269885723

Maxwell, J.A. (2012). A Realist Approach for Qualitative Research. Thousand Oaks, CA: Sage.

McNeal, J.U. (1992). Kids as customers: A handbook of marketing to children. New York, NY: Lexington Books.

Mitchell, L.M. (2006). Child-centered? Thinking critically about children's drawings as a visual research method. Visual Anthropology Review, 22(1), 60-73. doi: 10.1525/var.2006.22.1.60

Nanda, D., Hu, C., \& Bai, B. (2007). Exploring family roles in purchasing decisions during vacation planning: review and discussions for future research. Journal of Travel \& Tourism Marketing, 20(3-4), 107-125. doi: 10.1300/J073v20n03_08 
Nelson, K., \& Fivush, R. (2004). The emergence of autobiographical memory: A social cultural developmental theory. Psychological review, 111(2), 486-510. doi: 10.1037/0033-295X.111.2.486

Nickerson, N.P., \& Jurowski, C. (2001). The influence of children on vacation travel patterns. Journal of Vacation Marketing, 7(1), 19-30. doi: 10.1177/135676670100700102

Piaget, J., \& Inhelder, B. (2013). The growth of logical thinking from childhood to adolescence: An essay on the construction of formal operational structures. Abingdon, UK: Routledge.

Poria, Y., \& Timothy, D.J. (2014). Where are the children in tourism research? Annals of Tourism Research, 47, 93-95. doi: 10.1016/j.annals.2014.03.002

Punch, S. (2002). Research with children: The same or different from research with adults? Childhood, 9(3), 321-341. doi: 10.1177/0907568202009003005

Ruff, H.A., \& Lawson, K.R. (1990). Development of sustained, focused attention in young children during free play. Developmental psychology, 26(1), 85-93. doi: 10.1037/0012-1649.26.1.85

Russell, S.T., Crockett, L.J., \& Chao, R.K. (Eds.). (2010). Asian American parenting and parent-adolescent relationships. New York, NY: Springer.

Ryan, C. (1992). The child as a visitor. In J. R. B. Ritchie \& D. E. Hawkins (Eds.), World travel and tourism review: Indicators, trends and issues (Vol. 2, pp. 135-139). Wallingford, UK: CAB International.

Schänzel, H. (2012). The inclusion of fathers, children and the whole family group in tourism research on families. In H. Schänzel, I. Yeoman \& E. Backer (Eds.), Family tourism: Multidisciplinary perspectives (pp. 67-80). Bristol, UK: Channel View.

Schänzel, H.A. (2010). Whole-family research: Towards a methodology in tourism for encompassing generation, gender, and group dynamic perspectives. Tourism Analysis, 15(5), 555-569. doi: 10.3727/108354210X12889831783314

Schänzel, H.A., \& Smith, K.A. (2011). Photography and children: Auto-driven photoelicitation. Tourism Recreation Research, 36(1), 81-85. doi: 10.1080/02508281.2011.11081664

Schänzel, H.A., \& Smith, K.A. (2014). The socialization of families away from home: Group dynamics and family functioning on holiday. Leisure Sciences: An Interdisciplinary Journal, 36(2), 126-143. doi: 10.1080/01490400.2013.857624

Schänzel, H.A., Smith, K.A., \& Weaver, A. (2005). Family holidays: A research review and application to New Zealand. Annals of Leisure Research, 8(2-3), 105-123. doi: 10.1080/11745398.2005.10600965

Segumpan, R.G., Zahari, J.S.A., \& Jamaluddin, M.M. (2008). Tourism among Families in Northern Peninsular Malaysia. Asia-Pacific Social Science Review, 8(2), 129-139.

Shaw, S.M., Havitz, M.E., \& Delemere, F.M. (2008). 'I decided to invest in my kids' memories": Family vacations, memories, and the social construction of the family. Tourism Culture \& Communication, 8(1), 13-26. doi: 10.3727/109830408783900361

Shoham, A., \& Dalakas, V. (2005). He said, she said... they said: Parents' and children's assessment of children's influence on family consumption decisions. Journal of Consumer Marketing, 22(3), 152-160. doi: 10.1108/07363760510595977

Small, J. (2008). The absence of childhood in tourism studies. Annals of Tourism Research, 35(3), 772-789. doi: 10.1016/j.annals.2008.06.002

Swiezy, N.B., Matson, J.L., \& Box, P. (1993). The good behavior game: A token reinforcement system for preschoolers. Child \& Family Behavior Therapy, 14(3), 21 32. doi: 10.1300/J019v14n03_02 
Tagg, D.S., \& Seaton, A. (1995). The family vacation in Europe: Paedonomic aspects of choices and satisfactions. Journal of Travel \& Tourism Marketing, 4(1), 1-21. doi: $10.1300 / \mathrm{J} 073 \mathrm{v} 04 \mathrm{n} 0101$

Therkelsen, A. (2010). deciding on family holidays - Role distribution and strategies in use. Journal of Travel \& Tourism Marketing, 27(8), 765-779. doi: 10.1080/10548408.2010.526895

Thornton, P.R., Shaw, G., \& Williams, A.M. (1997). Tourist group holiday decision-making and behaviour: The influence of children. Tourism Management, 18(5), 287-297. doi: 10.1016/S0261-5177(97)00017-4

Tripathi, P., \& Sengupta, A. (2011). Increasing role of children in family purchase decisions. Indian Journal of Marketing, 41(6). Retrieved from http://www.indianjournalofmarketing.com/archives/2011/june2011.html

Turley, S.K. (2001). Children and the demand for recreational experiences: The case of zoos. Leisure Studies, 20(1), 1-18. doi: 10.1080/02614360122877

Valkenburg, P.M., \& Cantor, J. (2001). The development of a child into a consumer. Journal of Applied Developmental Psychology, 22(1), 61-72. doi: 10.1016/S01933973(00)00066-6

Wang, K.-C., Hsieh, A.-T., Yeh, Y.-C., \& Tsai, C.-W. (2004). Who is the decision-maker: The parents or the child in group package tours? Tourism Management, 25(2), 183194. doi: 10.1016/S0261-5177(03)00093-1

Ward, S., \& Wackman, D.B. (1972). Children's purchase influence attempts and parental yielding. Journal of Marketing Research, 9(3), 316-319.

Warner, L., \& Lynch, S. (2004). Preschool classroom management: 150 teacher-tested techniques. Lewisville, NC: Gryphon House.

Webster, S. (2012). Consumer kids and tourists - Creatively marketing a city to young tourists. In H. Schanzel, I. Yeoman \& E. Backer (Eds.), Family tourism: Multidisciplinary perspectives. Bristol, UK: Channel View.

Wilson, G., \& Wood, K. (2004). The influence of children on parental purchases during supermarket shopping. International Journal of Consumer Studies, 28(4), 329-336. doi: 10.1111/j.1470-6431.2004.00393.x

Wyness, M.G. (2012). Childhood and society: An introduction to the sociology of childhood. Basingstoke, UK: Palgrave Macmillan.

Young, L., \& Barrett, H. (2001). Adapting visual methods: Action research with Kampala street children. Area, 33(2), 141-152. doi: 10.1111/1475-4762.00017 